University of South Florida

DIGITAL COMMONS

Digital Commons @ University of

@ UNIVERSITY OF SOUTH FLORIDA

South Florida

$1-2004$

\title{
Simulated Changes in Shallow Groundwater and Vegetation Distributions Under Different Reservoir Operations Scenarios
}

\author{
Mark Cable Rains \\ University of California, mrains@usf.edu \\ Jeffery F. Mount \\ University of California \\ Eric W. Larsen \\ University of California
}

Follow this and additional works at: https://digitalcommons.usf.edu/gly_facpub

Part of the Geochemistry Commons, and the Geology Commons

\section{Scholar Commons Citation}

Rains, Mark Cable; Mount, Jeffery F.; and Larsen, Eric W., "Simulated Changes in Shallow Groundwater and Vegetation Distributions Under Different Reservoir Operations Scenarios" (2004). Geology Faculty Publications. 70.

https://digitalcommons.usf.edu/gly_facpub/70

This Article is brought to you for free and open access by the Geology at Digital Commons @ University of South Florida. It has been accepted for inclusion in Geology Faculty Publications by an authorized administrator of Digital Commons@ @niversity of South Florida. For more information, please contact digitalcommons@usf.edu. 


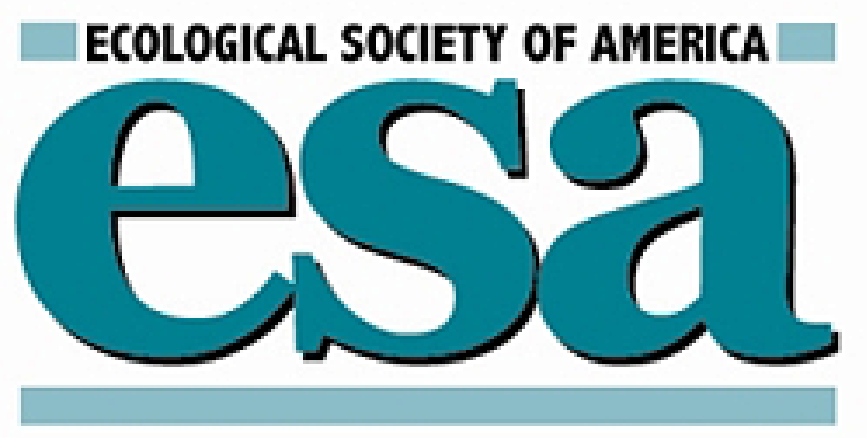

Simulated Changes in Shallow Groundwater and Vegetation Distributions under Different Reservoir Operations Scenarios

Author(s): Mark Cable Rains, Jeffrey F. Mount and Eric W. Larsen

Source: Ecological Applications, Vol. 14, No. 1 (Feb., 2004), pp. 192-207

Published by: Ecological Society of America

Stable URL: http://www.jstor.org/stable/4493530

Accessed: 05/06/2013 09:31

Your use of the JSTOR archive indicates your acceptance of the Terms \& Conditions of Use, available at http://www.jstor.org/page/info/about/policies/terms.jsp

JSTOR is a not-for-profit service that helps scholars, researchers, and students discover, use, and build upon a wide range of content in a trusted digital archive. We use information technology and tools to increase productivity and facilitate new forms of scholarship. For more information about JSTOR, please contact support@jstor.org. 


\title{
SIMULATED CHANGES IN SHALLOW GROUNDWATER AND VEGETATION DISTRIBUTIONS UNDER DIFFERENT RESERVOIR OPERATIONS SCENARIOS
}

\author{
Mark Cable Rains, ${ }^{1,3}$ Jeffrey F. Mount, ${ }^{2}$ and Eric W. Larsen ${ }^{2}$ \\ ${ }^{1}$ Hydrologic Sciences Graduate Group, University of California, Davis, California 95616 USA \\ ${ }^{2}$ Department of Geology, University of California, Davis, California 95616 USA
}

\begin{abstract}
The objectives of this study were to develop and use a linked groundwater and vegetation model to simulate groundwater and vegetation distributions in a riverine and reservoir-fringe system under different reservoir operations scenarios. This study was conducted where Little Stony Creek flows into East Park Reservoir on the east front of the Coast Range, northern California. A numerical groundwater model was used to model mean depth to groundwater during the growing season for water years 1980-1999 for each of five community types identified on the study site. Multiple vegetation models were developed, each of which described the probability that a given community type would occur primarily as a function of modeled mean depth to groundwater during the growing season and secondarily as a function of flooding. Four scenarios representing four different reservoir operations were simulated: existing condition, existing condition with late drawdown, full drawdown, and full pool. A groundwater backwater effect caused by the imposed reservoir stage extends to portions of the terrace, but the most pronounced effects occur on the delta. Consequently, the most pronounced changes in vegetation distributions also occur on the delta. Compared to the existing-condition scenario, modeled vegetation distributions do not change under the existing condition with late-drawdown scenario, a xeric herbaceous community type is greatly expanded under the full-drawdown scenario, and mesic herbaceous, scrub-shrub, and forested community types are greatly expanded under the full-pool scenario. The results of this study are twofold. First, the linked groundwater and vegetation model is relatively simple to construct and can be used to efficiently simulate multiple surface-water and groundwater management scenarios. Second, changes in reservoir operations can have pronounced effects on shallow groundwater and associated vegetation distributions in riverine and reservoir-fringe systems. Thus, the effects of changing reservoir operations must be considered if the management of shallow groundwater and associated plant and wildlife habitat resources is to be successful.
\end{abstract}

Key words: Bayesian model averaging; Bayesian model selection; Bayes' Theorem; groundwater modeling; MODFLOW; reservoir operations; shallow groundwater; vegetation distributions; vegetation modeling.

\section{INTRODUCTION}

More than $50 \%$ of the wetlands in the conterminous United States have been lost or severely degraded due to conversion from natural to agricultural or urban land uses (Dahl and Allord 1996). Estimates of loss or severe degradation exceed $90 \%$ for all wetland types in California (Bertoldi and Swain 1996) and 95\% for riparian systems in the Sacramento Valley of California (Greco 1999). Similar trends have been reported throughout the world (Moser et al. 1997). Thus, restoration and management are considered critical components of wetland and riparian system conservation efforts in the United States (U.S. Environmental Pro-

Manuscript received 20 September 2002; revised and accepted 21 April 2003. Corresponding Editor: J. S. Baron.

${ }^{3}$ Present address: Department of Geology, University of South Florida, Tampa, Florida 33620 USA.

E-mail: mrains@cas.usf.edu tection Agency and U.S. Department of Agriculture 1998) and throughout the world (Moser et al. 1997).

Hydrology is the primary forcing function in wetland and riparian systems (Mitsch and Gosselink 1993) and is the critical element in wetland and riparian system restoration and management efforts (Kentula 1996). Hydrology is particularly critical in riparian systems since it is the primary mechanism by which mass and energy are transported between uplands and downstream environments (Dahm et al. 1998); it is the primary control on the pathways and rates of biogeochemical processing of dissolved and particulate matter (Gosselink and Turner 1978, Vervier et al. 1993, Pusch et al. 1998); it provides multidimensional environmental gradients that support diverse metazoan populations which serve as critical pathways and mechanisms by which energy is transferred in riparian food webs (Ward et al. 1998); and it plays critical roles in tree recruitment and persistence (McBride and Strahan 1984, Dawson and Ehleringer 1991, Mensforth et al. 1994, 


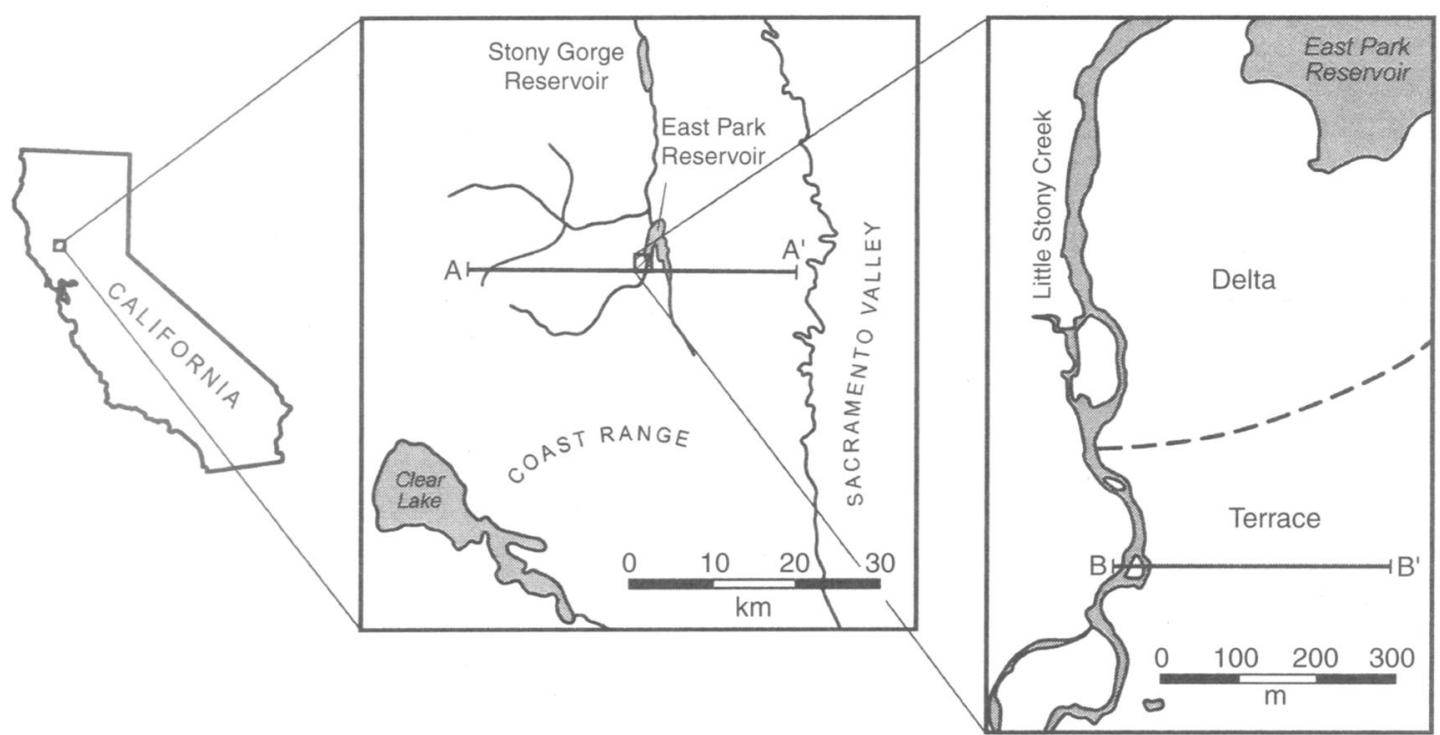

FIG. 1. Regional and local settings showing the major physiographic and hydrographic features and the locations of the regional and local-scale cross sections $\left(\mathrm{A}-\mathrm{A}^{\prime}\right.$ and $\mathrm{B}-\mathrm{B}^{\prime}$, respectively).

van Splunder et al. 1995, Stromberg et al. 1996, Mahoney and Rood 1998, Scott et al. 1998, Amlin and Rood 2002). Unfortunately, while a great deal is known about the surface-water hydrology of wetland and riparian systems, comparatively little is known about the shallow groundwater hydrology of wetland and riparian systems (Kentula 1996).

This study is part of a larger effort focused on the management of surface water and shallow groundwater and associated plant and wildlife habitat resources in riverine and reservoir-fringe systems. The overall objective of this larger effort is to develop concepts and tools for the planning, implementation, and monitoring stages of riverine and reservoir management efforts. In the first step, the primary sources of the shallow groundwater were identified (Rains and Mount 2002). In the second step, the roles of stream discharge, regional groundwater discharge, and reservoir stage in controlling shallow groundwater were characterized (Rains 2002). The specific objectives of this study were to develop and use a linked groundwater and vegetation model to simulate groundwater and vegetation distributions in a riverine and reservoir-fringe system under different reservoir operations scenarios. Changes in reservoir operations are of particular interest since regionally unique plant and wildlife habitats in reservoirfringe systems can be impacted when reservoirs are decommissioned or reservoir operations are otherwise altered (Cairns and Palmer 1993, Shuman 1995, Childers et al. 2000).

\section{Site DesCRIPTION}

\section{Location and character}

This study was conducted where Little Stony Creek flows into East Park Reservoir on the east front of the
Coast Range, northern California (Fig. 1). The watershed area is $\sim 119 \mathrm{~km}^{2}$. Most of the upper watershed is below $1500 \mathrm{~m}$, with maximum elevations exceeding $1800 \mathrm{~m}$. Hillslopes typically vary between $15 \%$ and $75 \%$.

Little Stony Creek flows down the east front of the Coast Range through a narrow, high-gradient, bedrock canyon. At the canyon mouth, Little Stony Creek flows north through a broad, low-gradient, alluvial valley for $\sim 3 \mathrm{~km}$ before discharging to East Park Reservoir. Prior to the construction of East Park Reservoir, the site comprised a bedload-dominated, braided river with a broad, alluvial terrace supporting oak savannah. East Park Reservoir was constructed in 1910 and the subsequent change in base level resulted in the development of a delta where Little Stony Creek flows into East Park Reservoir (Fig. 1). While the terrace still supports oak savannah, the delta now supports a large, regionally unique emergent marsh, sedge meadow, and riparian forest complex. Long-term monitoring indicates that the juxtaposition of these diverse habitats supports high diversity resident and migratory bird populations including large populations of the Tricolored Blackbird (Agelaius tricolor), a California State Species of Special Concern (Hamilton 1998).

\section{Geology and hydrogeology}

The Little Stony Creek alluvial valley is bound on the west by the Franciscan Complex and underlain and bound on the east by the Great Valley Group (Fig. 2). Surface deposits on the terrace are floodplain silts and sands to $\sim 1 \mathrm{~m}$. Surface deposits on the delta are floodplain silts and sands to $\sim 1 \mathrm{~m}$ with natural levee and crevasse splay silts and sands to $\sim 2$ m near the channel. Shallow subsurface deposits underlying the terrace and 

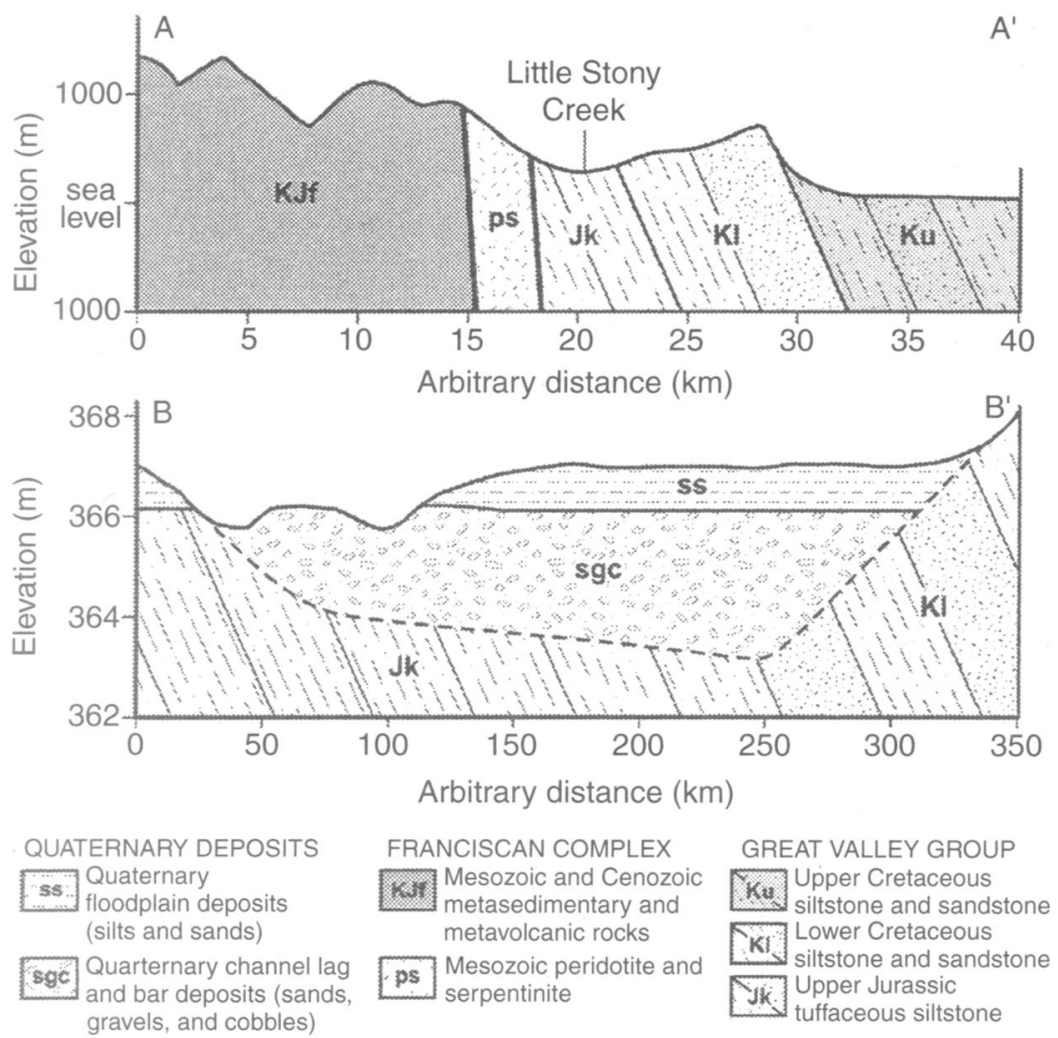

FIG. 2. Regional and local-scale cross sections (A-A' and B-B', respectively) based upon field observations and previous studies (Jennings and Strand 1960, Brown 1964, Rains 2002). Vertical exaggerations for the regional and local-scale cross sections are approximately $5 \times$ and $25 \times$, respectively.

delta are channel lag and bar sands and gravels of variable depths to $\sim 3 \mathrm{~m}$. The channel lag and bar sands and gravels underlying the terrace and delta are similar in depth and composition which indicates that they were deposited prior to delta formation and that the delta is primarily a surficial feature (Rains 2002). Described as a single, composite sample, the channel lag and bar sands and gravels are very poorly sorted, sandy medium gravels with $d_{10}, d_{50}$, and $d_{90}$ of $0.6,9.0$, and $39.8 \mathrm{~mm}$, respectively (where $d_{10}, d_{50}$, and $d_{90}$ are the diameters that are larger than $10 \%, 50 \%$ and $90 \%$ of the grains, respectively; Rains 2002). The local groundwater flow system is unconfined and occurs primarily in the channel lag and bar sands and gravels. Rains (2002) estimated the hydraulic conductivity of the local groundwater flow system to be $\sim 400 \mathrm{~m} / \mathrm{d}$ using grain size data and the Hazen method (Hazen 1911) which is applicable to coarse-grained sediments where the $d_{10}$ is $\sim 0.1-3.0 \mathrm{~mm}$ (Fetter 1994).

\section{Climate and hydrology}

Precipitation, evapotranspiration, and stream discharge are strongly seasonal with pronounced wet and dry seasons (Rains 2002). Local shallow groundwater is recharged primarily by Little Stony Creek water and Franciscan Complex groundwater, with Little Stony
Creek the more prominent source of local shallow groundwater in the wet season and Franciscan Complex groundwater the more prominent source of local shallow groundwater in the dry season (Fig. 3) (Rains and Mount 2002). Little Stony Creek is a more prominent source of groundwater in the wet season than in the dry season because Little Stony Creek flows continuously through the study reach in the wet season and intermittently through the study reach in the dry season. Franciscan Complex groundwater discharges to local shallow groundwater in both wet and dry seasons primarily because the local groundwater flow system is a regional low that lies perpendicular to the Franciscan Complex groundwater flow path.

\section{Methods}

\section{Groundwater model}

A numerical groundwater model was constructed using MODFLOW-2000, a block-centered finite-difference code for simulating groundwater flow systems (Harbaugh et al. 2000). MODFLOW-2000 is a widely used, well-documented, and verified model code (Anderson and Woessner 1992). Simulations were run with the Ground-Water Flow Process Basic (BCF6) package; the Recharge (RCH), Evapotranspiration (EVT), and the Flow and Head Boundary (FHB1) stress packages; 

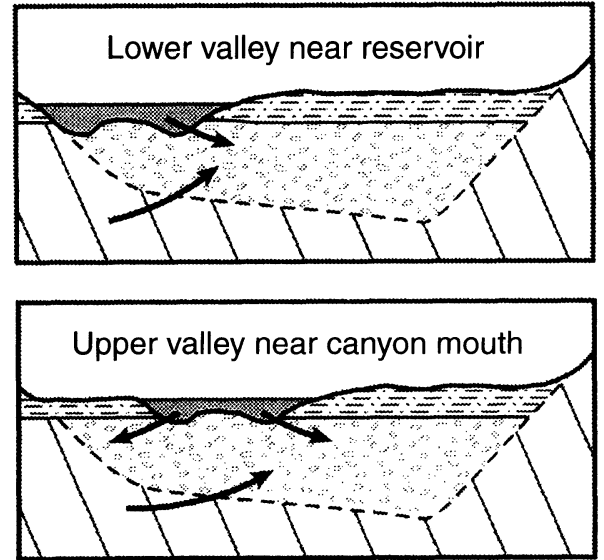

b
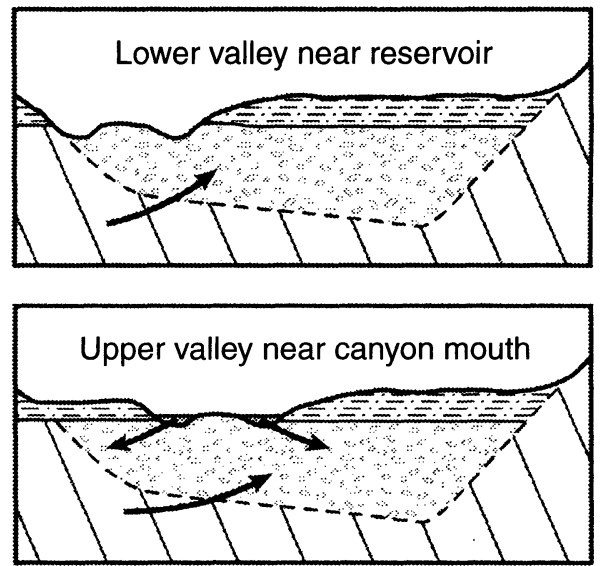

FIG. 3. Conceptual model of groundwater recharge to the local groundwater flow system for hypothetical cross sections on the lower alluvial valley near the reservoir and the upper alluvial valley near the canyon mouth. Figures are for (a) the wet season and (b) the dry season and are modified from Rains and Mount (2002).

and the Strongly Implicit Procedure (SIP) solver package (Leake and Lilly 1997, Harbaugh et al. 2000). Preand post-processing including finite-difference grid generation were performed with Argus ONE v. 4.2.0w, a model-independent GIS for numerical modeling (Argus Holdings, Ltd., Herzelia, Israel).

The model domain had 202 active blocks or nodes (Fig. 4). Node spacing was $31.62 \mathrm{~m}$, with each node representing 0.10 ha. The model domain was one layer in thickness and was unconfined. Topographic eleva-

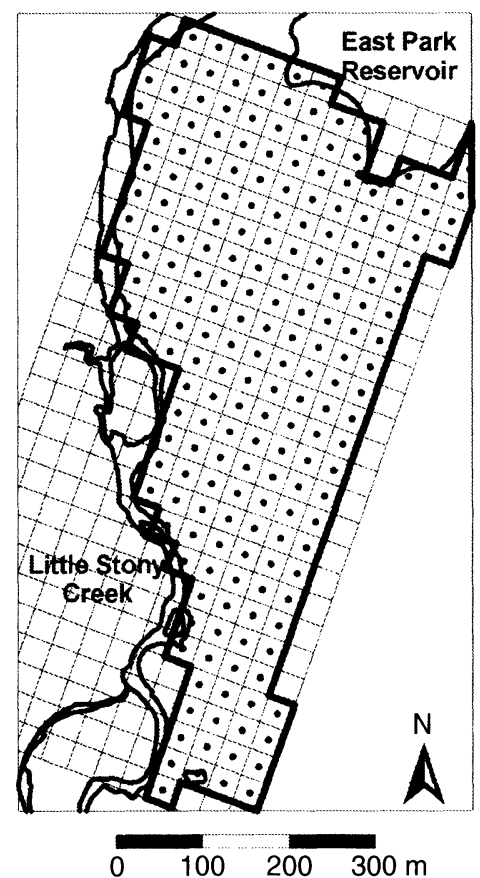

FIG. 4. Groundwater and vegetation model domain. The dark line delineates the active model domain, the light lines delineate the blocks, and the points indicate the locations of the block-centered nodes. tion at each node was interpolated to the nearest 0.1 $\mathrm{m}$ from a photogrammetic survey map with 0.3 -m contour intervals.

The eastern boundary was the margin of the Great Valley Group. This was a no-flow boundary because the Great Valley Group does not contribute appreciable inflow to the local groundwater flow system (Rains and Mount 2002). The western and northern boundaries were Little Stony Creek and the full-pool elevation contour of East Park Reservoir, respectively. Groundwater inflow and outflow on these boundaries were represented with specified-head conditions because hydraulic heads are functions of stream stage on the upper reach and stream stage and reservoir stage on the lower reach (Rains 2002). The southern boundary was a narrow part of the alluvial valley. This was a specifiedhead boundary and was set equal to stream stage because stream stage and hydraulic heads are essentially identical over short distances on the upper reach (Rains 2002). All specified-head boundaries were simulated using the Flow and Head Boundary (FHB1) stress package (Leake and Lilly 1997). The area west of Little Stony Creek was not part of the model domain because Little Stony Creek is bound on the west by incised alluvial fan deposits.

Total monthly accumulated precipitation and maximum, minimum, and mean monthly temperature for water years 1980-1999 were obtained from a joint U.S. Bureau of Reclamation and National Oceanic and Atmospheric Administration station located $4 \mathrm{~km}$ across the reservoir near East Park Dam. Reference evapotranspiration was calculated using the Hargreaves equation, which provides estimates consistent with other energy balance approaches (Hargreaves and Samani 1982, 1985, Jensen et al. 1990). Reference evapotranspiration was assumed to be approximately equal to actual evapotranspiration since groundwater levels are at 
or near the ground surface and well within the rooting zones throughout most of the model period. The evaporation extinction depth was set at $3.3 \mathrm{~m}$ below the ground surface, which is the approximate bottom of the local groundwater flow system (Rains 2002).

Recharge from the Franciscan Complex groundwater flow system to the local groundwater flow system was treated as diffuse recharge to each node. Recharge from the Franciscan Complex groundwater flow system to the local groundwater flow system was calculated using dry-season hydrometric (Rains 2002) and geochemical (Rains and Mount 2002) data. When the dry-season hydrometric and geochemical data were collected, Little Stony Creek water and Franciscan Complex groundwater recharged local shallow groundwater in the upper alluvial valley, while only Franciscan Complex groundwater recharged local shallow groundwater in the lower alluvial valley (Fig. 3). Down-valley groundwater flow was calculated using hydrometric data from two crossvalley transects in the lower alluvial valley. Calculated down-valley groundwater flow increased $23 \%$ between the two cross-valley transects. This estimate was validated using geochemical data from the two cross-valley transects. The relative contributions of Little Stony Creek water and Franciscan Complex groundwater to local shallow groundwater were calculated with a massbalance mixing model using $\delta^{18} \mathrm{O}$ as a conservative, natural tracer (Rains and Mount 2002). The calculated relative contribution of Franciscan Complex groundwater increased $20 \%$ between the two cross-valley transects. Thus, hydrometric and geochemical data indicated that down-valley groundwater flow increased between the two cross-valley transects by $\sim 20 \%$ largely due to groundwater discharge from the Franciscan Complex groundwater flow system. The $210-\mathrm{m}^{3} / \mathrm{d}$ increase in down-valley groundwater flow between the two cross-valley transects spread equally over the $126000 \mathrm{~m}^{2}$ of valley floor between the two cross-valley transects equals $\sim 0.002 \mathrm{~m} / \mathrm{d}$ of groundwater recharge. This value was used for all time steps.

Reservoir stage for water years 1980-1999 was obtained from a U.S. Bureau of Reclamation gage located $4 \mathrm{~km}$ across the reservoir near East Park Dam, while stream stage for water years 1980-1999 was obtained by combining modeling and field measurements. A synthetic hydrograph for water years 1921-1998 was developed by correlating gauging station records (Searcy 1960, Searcy and Hardison 1960). Mean daily discharge at Little Stony Creek above East Park Reservoir near Lodoga, California (U.S. Geological Survey Gage No. 11384600) was related to mean daily discharge at Thomes Creek at Paskenta, California (U.S. Geological Survey Gage No. 11382000) for the overlapping water years 1967-1982. The model was calibrated with 12 randomly selected water years and validated with four randomly selected water years. Stream stage and discharge were measured hourly for water year 1999 (Rains 2002). The rating curve developed for water year 1999 was assumed to be valid for water years 1980-1998 and was used to transform modeled discharges into modeled stream stages on the study reach. Stream stage was interpolated along the Little Stony Creek boundary based upon hourly measurements of surface-water slope between the upper and lower reaches, and the lower reach and the reservoir, taken during water year 1999.

The model was run on one-month time steps, with boundary conditions set to their monthly means. The model was run to steady state because hydraulic heads respond to changes in stream and reservoir stage in the span of hours (Rains 2002). The growing season was defined as being from February through August because field observations indicated that this interval encompassed the growing seasons for most of the species on the site. Mean monthly hydraulic heads were averaged to provide mean hydraulic heads during the growing season. Mean hydraulic heads during the growing season were subtracted from ground surface elevations to provide mean depths to groundwater during the growing season.

\section{Vegetation sampling}

Vegetation was sampled in 32 plots in late June and early July 1999. Vegetation was sampled in nested plots, with trees $\left(>6 \mathrm{~m}\right.$ in height) sampled in $100-\mathrm{m}^{2}$ plots, small trees $\left(<6 \mathrm{~m}\right.$ in height) sampled in $16-\mathrm{m}^{2}$ plots, seedlings and shrubs sampled in $4-\mathrm{m}^{2}$ plots, and herbs sampled in 1- $\mathrm{m}^{2}$ plots (Mueller-Dombois and Ellenberg 1974). In each plot, species composition was recorded with identification and nomenclature consistent with The Jepson Manual (Hickman 1993). Three observers independently estimated raw percent cover, the raw percent cover estimates were averaged, and abundance values were assigned based upon modified Daubenmire cover classes: $<1 \%, 1-5 \%, 6-15 \%, 16-$ $25 \%, 26-50 \%, 51-75 \%, 76-95 \%$, and $>95 \%$. Cover classes were converted to cover class midpoints for data analyses.

\section{Vegetation classification}

Two-way indicator species analysis (TWINSPAN; Hill 1979) was used to classify the 32 vegetation plots into five community types. Uncommon, low-abundance species can have disproportionate effects in classification efforts. One possible result is that plots that share uncommon, low-abundance species may be classified together even if they have little or nothing else in common and have no meaningful ecological relationship (Zedler 1977, Pasternack et al. 2000). To reduce the possibility of this occurrence, each species was assigned its maximum observed raw percent cover value and the values were plotted cumulatively. A substantial change in slope was considered indicative of the presence of groups of uncommon, low-abundance species and common, high-abundance species. The uncommon, low-abundance species, in this case those species with 
no occurrences that equaled or exceeded $5 \%$, were omitted from the classification effort. The complete matrix of species composition and abundance was restored following the classification effort, thereby restoring uncommon, low-abundance species to the community type descriptions.

\section{Vegetation model}

A vegetation model was constructed based on direct gradient analysis, in which vegetation distributions are assumed to be functions of environmental gradients (Whittaker 1967, Jongman et al. 1987, ter Braak and Prentice 1988). Though the specific modeling approach differs, this modeling effort nevertheless builds on previous efforts to model riparian vegetation as a function of surface water or groundwater in riparian ecosystems (Franz and Bazzaz 1977, Auble et al. 1994, Springer et al. 1999, Primack 2000). Most previous efforts employed direct gradient analysis and a single environmental gradient. Auble et al. (1994) and Primack (2000) modeled community types as functions of inundation duration using probabilistic approaches in which the probability that a given community type would occur in a given arbitrary inundation duration class was determined by field observations. Springer et al. (1999) modeled potential woody riparian vegetation establishment zones as functions of minimum and maximum depths to groundwater, the minimum and maximum depths to groundwater being determined from observational data from previous regional studies. Franz and Bazzaz (1977) modeled individual species as functions of elevation relative to stream stage using a probabilistic approach where species distributions were assumed to be described by normal density functions defined by sample means and standard deviations.

The approach employed in this study is most similar to the approach employed by Franz and Bazzaz (1977). The primary difference in this study is that two gradients are employed since community types are modeled primarily as functions of mean depth to groundwater during the growing season and secondarily as functions of flooding. The groundwater model was used to model mean depth to groundwater during the growing season for water years 1980-1999 at each of the 32 vegetation plots. These data were used to calculate sample means and standard deviations of the mean depth to groundwater during the growing season for each community type. The probability that a community type would occur as a function of mean depth to groundwater during the growing season was calculated using Bayes' Theorem:

$$
p(g \mid d)=\frac{f(d \mid g) \pi(g)}{\sum f(d \mid g) \pi(g)}
$$

where $p(g \mid d)$ was the posterior probability that a community type, $g$, would occur as a function of mean depth to groundwater during the growing season, $d ; f(d \mid g)$ was a function describing the distribution of the mean depths to groundwater during the growing season, $d$, in a community type, $g$; and $\pi(g)$ was the prior probability that a community type, $g$, would occur independent of the mean depth to groundwater during the growing season, $d$. The functions, $f$, were assumed to be normal density functions with means and standard deviations equal to the sample means and standard deviations of the modeled mean depth to groundwater during the growing season in each sampled community type. With one exception, the prior probabilities were set equal to one another, i.e., were set such that the probability of occurrence of each community type was based solely on mean depth to groundwater during the growing season. The one exception was that one community type, riverine forest, only occurred where surface water flooding occurred. Thus, the prior probability of riverine forest was set to zero in terrace blocks where surface water flooding does not occur.

This approach resulted in multiple models. Each model described the probability that a given community type would occur primarily as a function of modeled mean depth to groundwater during the growing season and secondarily as a function of flooding. Models were employed block-by-block using Bayesian model selection and Bayesian model averaging (Hoeting et al. 1999, Wasserman 2000). In Bayesian model selection, modeled groundwater data were used to select the single best model from the suite of models, while in Bayesian model averaging, modeled groundwater data were used to average the results from the suite of models. In Bayesian model selection, the community type with the highest probability of occurrence was assigned to the entire block. In Bayesian model averaging, the probabilities of occurrence of each community type were used as weights that were multiplied by the area of the entire block to provide weighted averages of each community type. These probabilities also were used to calculate variances since, if the probability of community type, $g$, occurring at block $i$, is $p_{g i}$, then the variance is $p_{g i}\left(1-p_{g i}\right)$. Bayesian model selection results were used for graphical output where each block had to be assigned to a discrete community type. Bayesian model averaging results were used for tabular output.

\section{Scenarios}

The growing season was simulated for four scenarios representing four different reservoir operations: existing condition, existing condition with late drawdown, full drawdown, and full pool. Mean monthly stream stages for water years 1980-1999 were used in all simulations. In the existing-condition scenario, mean monthly reservoir stages for water years 1980-1999 were used for all months. Results of the existing-condition scenario were used to generally validate the Bayesian model selection results and to provide baseline data for further comparisons. In the existing condition with late-drawdown scenario, mean monthly res- 


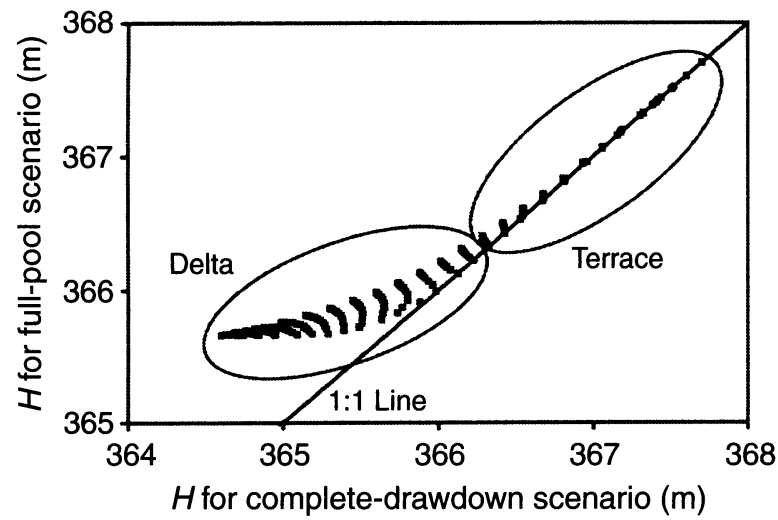

b

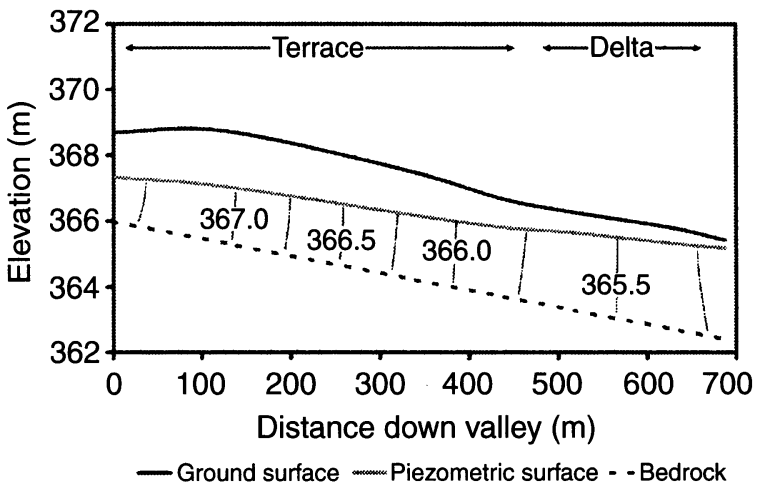

FIG. 5. Groundwater backwater effect for (a) modeled and (b) measured cases. The groundwater backwater effect is largely restricted to the delta in both modeled and measured cases. In (a), $H$ stands for hydraulic head, or the fluid potential for flow through porous media. Water flows from areas of high hydraulic head to areas of low hydraulic head. In the special cases illustrated here, $H$ is also the water table elevation. Fig. 5b is from Rains (2002).

ervoir stages for water years 1980-1999 were used for the months of February through June, then a completely drained reservoir was used for the months of July through September. For the full-drawdown and fullpool scenarios, completely drained and completely full reservoirs were used for all months, respectively.

\section{RESULTS}

\section{Groundwater modeling}

The groundwater model was generally validated by comparing modeled inflows and hydraulic heads to estimated inflows and measured hydraulic heads for 15 March 1999 and 19 July 1999, these two days being well studied and representative of wet- and dry-season conditions, respectively (Rains 2002). The model was run to steady state with boundary conditions set to their daily means. Model results were generally validated by comparing modeled and estimated inflows to the model domain, and by comparing modeled and measured hydraulic heads with paired $t$ tests using StatView for Windows v. 5.0.1 (SAS Institute, Inc., Cary, North Carolina, USA). Modeled and estimated inflows to the model domain were within $3 \%$ and $20 \%$ of one another on 15 March 1999 and 19 July 1999, respectively. These discrepancies were considered acceptable since there are substantial uncertainties, particularly with respect to inflows due to groundwater recharge from Little Stony Creek and the Franciscan Complex groundwater flow system and outflows due to evapotranspiration. Modeled and measured groundwater levels were not significantly different on either 15 March $1999(P$ $=0.012)$ or 19 July $1999(P<0.001)$.

The groundwater model was only generally validated, so results should be interpreted with caution. Simulation results indicate that a groundwater backwater effect caused by the imposed reservoir stage extends up valley, and that the geographic extent and degree of this groundwater backwater effect is dependent upon reservoir operations. The groundwater backwater effect can be seen in a scattergram of mean modeled hydraulic heads at each model node for the full-pool and fulldrawdown scenarios (Fig. 5). All nodes that plot above the $1: 1$ line are affected by the groundwater backwater effect. The groundwater backwater effect is largely confined to the delta, with the largest effect on the lower delta where hydraulic heads for the full-pool scenario exceed hydraulic heads for the full-drawdown scenario by more than $1 \mathrm{~m}$. The physical effect of this groundwater backwater effect can be seen in a longitudinal cross section of ground surface, measured hydraulic head on 15 March 1999, and the approximate bedrock contact (Fig. 5) (Rains 2002). Groundwater flows down the valley, encounters the reservoir, and flows upward where it accumulates in shallow groundwater storage prior to discharging at or near the reservoir fringe. This creates a stable, shallow groundwater environment on the lower delta.

\section{Existing vegetation}

There were 62 vascular plant species observed in the 32 plots. Most observed species are typical to alluvial valleys and riparian areas throughout California (Hickman 1993, Sawyer and Keeler-Wolf 1995). Three TWINSPAN divisions separated the 32 plots into five community types that were arranged along a gradient of mean depth to groundwater during the growing season: grassland, riverine forest, sedge meadow, willow forest, and emergent marsh (Figs. 6 and 7, Table 1).

Grassland is a species-poor, herbaceous community type dominated by xeric grasses and herbs. The most common species are Bromus hordeaceous and Centaurea solstitialis. There also are widely scattered Quercus lobata, though none occurred in the vegetation plots. This community type would be classified as California 


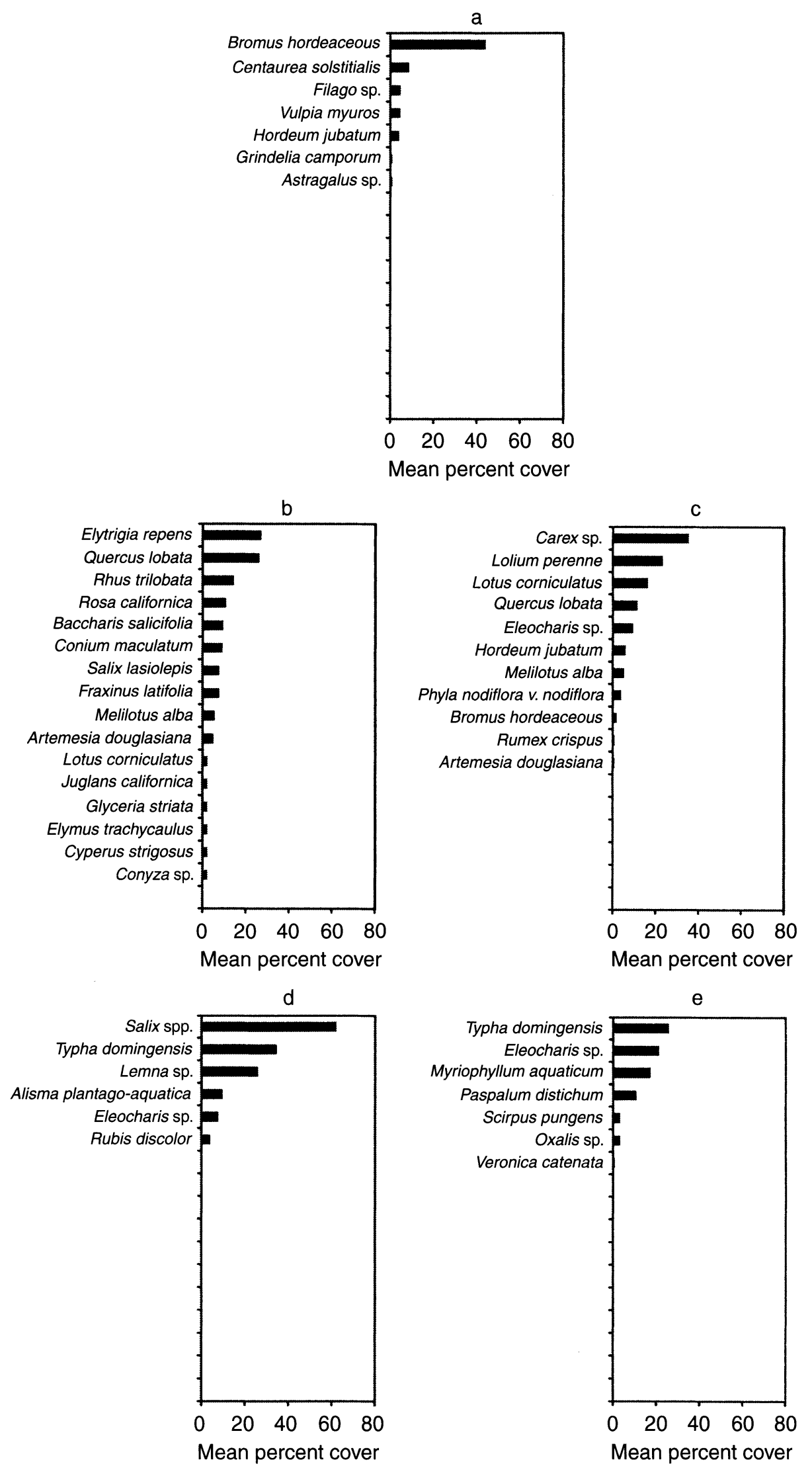

FIG. 6. Species composition and mean percent cover in the plots for (a) grassland, (b) riverine forest, (c) sedge meadow, (d) willow forest, and (e) emergent marsh. 


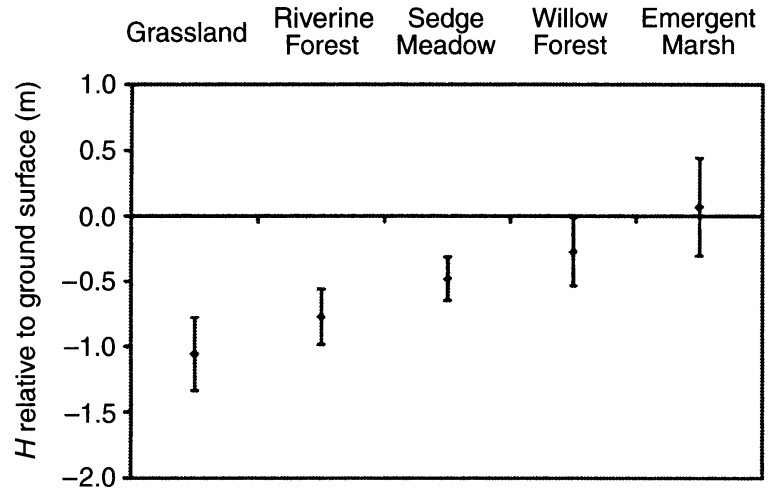

FIG. 7. Groundwater levels relative to ground surface during the growing season in each community type (means \pm 1 SD). $H$ stands for hydraulic head, or the fluid potential for flow through porous media. Water flows from areas of high hydraulic head to areas of low hydraulic head. In the special cases illustrated here, $H$ is also the water table elevation.

annual grassland series by Sawyer and Keeler-Wolf (1995). Grassland occurs exclusively on the terrace where groundwater is relatively deep and flooding does not occur. Modeled mean and standard deviation of the mean depth to groundwater during the growing season are $1.06 \mathrm{~m}$ and $0.26 \mathrm{~m}$, respectively.

Riverine forest is a species-rich, multistoried, forested community type. The most common trees are Quercus lobata, Salix lasiolepis, and Fraxinus latifolia, the most common shrubs are Rhus trilobata, Rosa californica, and Baccharis salicifolia, and the most common herbs are Elytrigia repens and Conium maculatum. This community type would be classified as valley oak series by Sawyer and Keeler-Wolf (1995). Riverine forest occurs exclusively on well-drained flood deposits such as active floodplains, natural levees, and crevasse splays. Modeled mean and standard deviation of the mean depth to groundwater during the growing season are $0.77 \mathrm{~m}$ and $0.21 \mathrm{~m}$, respectively.

Sedge meadow is a densely vegetated, herbaceous community type dominated by mesic to xeric grasses and herbs. The most common species are Carex sp., Lolium perrene, and Lotus corniculatus. This community type would be classified as either sedge meadow or introduced perennial grassland series by Sawyer and
Keeler-Wolf (1995). Sedge meadow occurs on scoured areas of the upper to middle delta such as abandoned floodways and abandoned channels. Modeled mean and standard deviation of the mean depth to groundwater during the growing season are $0.48 \mathrm{~m}$ and $0.17 \mathrm{~m}$, respectively.

Willow forest is a species-poor, scrub-shrub to forested community type. The only trees and shrubs are mixed Salix spp., which could not be identified to species due to a near-complete lack of catkins, and the most commons herbs are Typha domingensis and Lem$n a$ sp. This community type would be classified as mixed willow series by Sawyer and Keeler-Wolf (1995). Willow forest occurs on the reservoir fringe and on scoured areas on the middle to lower delta such as an abandoned floodway and an abandoned channel. Modeled mean and standard deviation of the mean depth to groundwater during the growing season are $0.27 \mathrm{~m}$ and $0.26 \mathrm{~m}$, respectively.

Emergent marsh is a species-poor, herbaceous community type dominated by mesic grasses and herbs. The most commons species are Typha domingensis, Eleocharis sp., and Myriophyllum aquaticum. This community type would be classified as cattail series by Sawyer and Keeler-Wolf (1995). Emergent marsh occurs on the reservoir fringe and on scoured surfaces on the middle to lower delta such as an abandoned channel. Modeled mean and standard deviation of the mean depth to groundwater during the growing season are $-0.07 \mathrm{~m}$ (i.e., $0.07 \mathrm{~m}$ above the ground surface) and $0.38 \mathrm{~m}$, respectively.

\section{Vegetation modeling}

The vegetation model comprises multiple models, each of which describes the probability that a given community type will occur primarily as a function of mean depth to groundwater during the growing season and secondarily as a function of flooding. There are two separate model outputs, one for the floodplain and delta where the prior probabilities for each community type are set equal to one another, and one for the terrace where the prior probability of riverine forest is set to zero while the prior probabilities of the remaining community types are set equal to one another (Fig. 8).

TABLE 1. Percent cover by taxa of given wetland indicator status (Reed 1988) in each of the community types.

\begin{tabular}{lccccccc}
\hline \hline Community type & ND & NL & UPL & FACU & FAC & FACW & OBL \\
\hline Grassland & 1 & 17 & 0 & 77 & 5 & 0 & 0 \\
Riverine forest & 2 & 32 & 0 & 4 & 31 & 28 & 3 \\
Sedge meadow & 1 & 0 & 0 & 6 & 49 & 36 & 8 \\
Willow forest & 6 & 0 & 0 & 0 & 0 & 43 & 51 \\
Emergent marsh & 4 & 0 & 0 & 0 & 0 & 0 & 96 \\
\hline
\end{tabular}

Note: $\mathrm{ND}=$ no data, due to unknown taxonomy; $\mathrm{NL}=$ not listed, often assumed to be upland; UPL $=$ upland, $<1 \%$ occurrence in wetlands; FACU $=$ facultative upland, $1-33 \%$ occurrence in wetlands; FAC $=$ facultative, $>33-66 \%$ occurrence in wetlands; FACW $=$ facultative wetland, $>66-99 \%$ occurrence in wetlands; OBL $=$ obligate, $>99 \%$ occurrence in wetlands. 
a

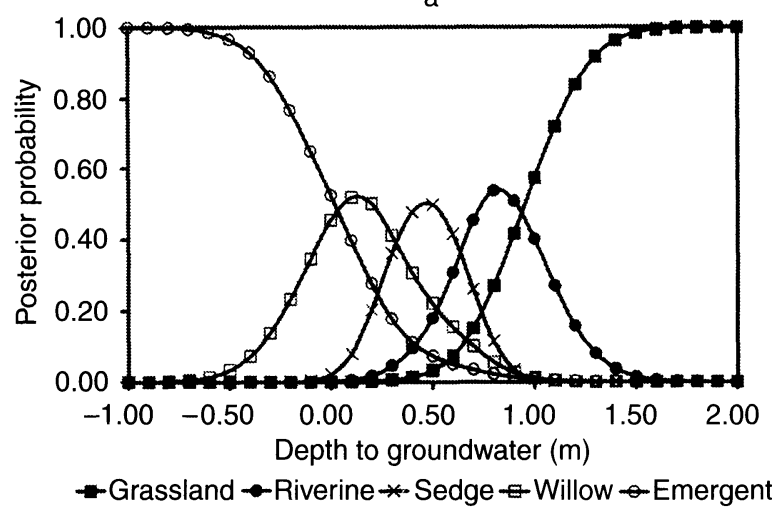

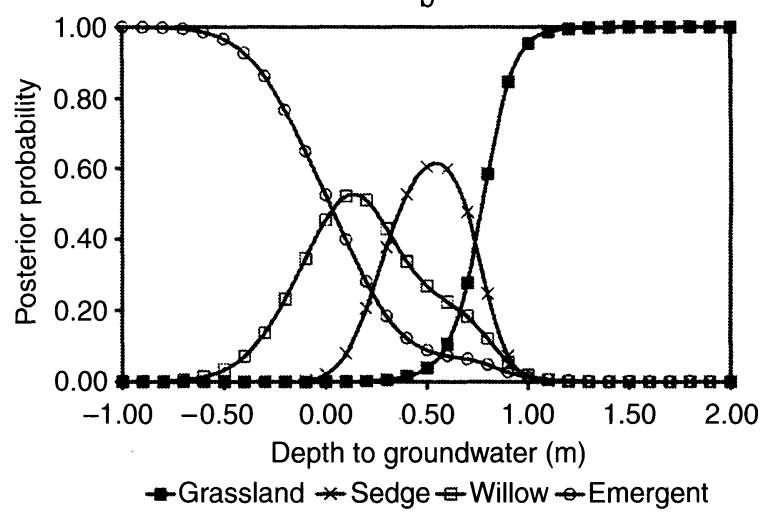

FIG. 8. Bayesian model output for (a) the floodplain and delta and (b) the terrace.

The results of the Bayesian model selection procedure were generally validated by comparison to existing conditions. The 32 blocks used in vegetation model calibration were omitted, and 30 of the remaining 170 blocks were randomly selected for the validation procedure. The results are summarized in an error matrix along with the producer, user, and overall accuracies (Table 2; Lilles and Kiefer 1994). The overall accuracy of the Bayesian model selection effort was 0.87 . The errors were three riverine forest blocks and one emergent marsh block, all four of which were incorrectly classified as sedge meadow. The results of the Bayesian model averaging procedure were not validated since existing areas of the five community types are unknown.

The Bayesian model selection results were only generally validated, and the Bayesian model averaging results were not validated at all, so these results should be interpreted with caution. The Bayesian model selection and Bayesian model averaging results are presented in Fig. 9 and Table 3, respectively. Results for the existing condition and existing condition with latedrawdown scenarios are identical. In both scenarios, sedge meadow is the predominant community type, though grassland, riverine forest, and willow forest are prominent. In the full-drawdown scenario, grassland is the predominant community type. The expansion of grassland is largely at the expense of riverine forest.
Sedge meadow, willow forest, and emergent marsh are only slightly reduced. In the full-pool scenario, willow forest and emergent marsh are the predominant community types, while grassland, riverine forest, and sedge meadow are all greatly reduced.

\section{Discussion}

\section{Model utility}

This linked groundwater and vegetation model is a practical approach to understanding the behavior of riverine and reservoir-fringe systems and to generating hypotheses about the way that riverine and reservoirfringe systems might develop under different reservoir operations. The linked groundwater and vegetation model relies upon standard techniques in hydrogeology, plant ecology, and statistical analysis. Input data are reasonably easy to obtain. The construction of the linked groundwater and vegetation model can be time consuming. However, multiple simulations can be run efficiently once the linked groundwater and vegetation model is constructed.

The modeled vegetation distributions represent equilibrium conditions given sufficient yet indeterminate time for community type changes to occur. Response times vary by species or functional group. Herbaceous species might respond on the scale of years, while woody species might respond on the scale of decades.

TABLE 2. Error matrix along with producer, user, and overall accuracies for the Bayesian model selection procedure.

\begin{tabular}{|c|c|c|c|c|c|c|c|c|}
\hline \multirow{2}{*}{$\begin{array}{c}\text { Classification } \\
\text { data }\end{array}$} & \multicolumn{6}{|c|}{ Reference data } & \multicolumn{2}{|c|}{ Accuracy } \\
\hline & $\mathrm{G}$ & $\mathrm{RF}$ & SM & WF & EM & Total & Producer & User \\
\hline G & 5 & 0 & 0 & 0 & 0 & 5 & 1.00 & 1.00 \\
\hline RF & 0 & 12 & 0 & 0 & 0 & 12 & 0.80 & 1.00 \\
\hline SM & 0 & 3 & 7 & 0 & 0 & 10 & 0.88 & 0.70 \\
\hline WF & 0 & 0 & 0 & 1 & 0 & 1 & 1.00 & 1.00 \\
\hline EM & 0 & 0 & 1 & 0 & 1 & 2 & 1.00 & 0.50 \\
\hline Total & 5 & 15 & 8 & 1 & 1 & 30 & & \\
\hline
\end{tabular}

Notes: $\mathrm{G}=$ grassland, $\mathrm{RF}=$ riverine forest, $\mathrm{SM}=$ sedge meadow, $\mathrm{WF}=$ willow forest and $\mathrm{EM}=$ emergent marsh. Overall accuracy $=0.87$. 


Grassland
Riverine Forest
Sedge Meadow
ZWillow Forest
IIIEmergent Marsh
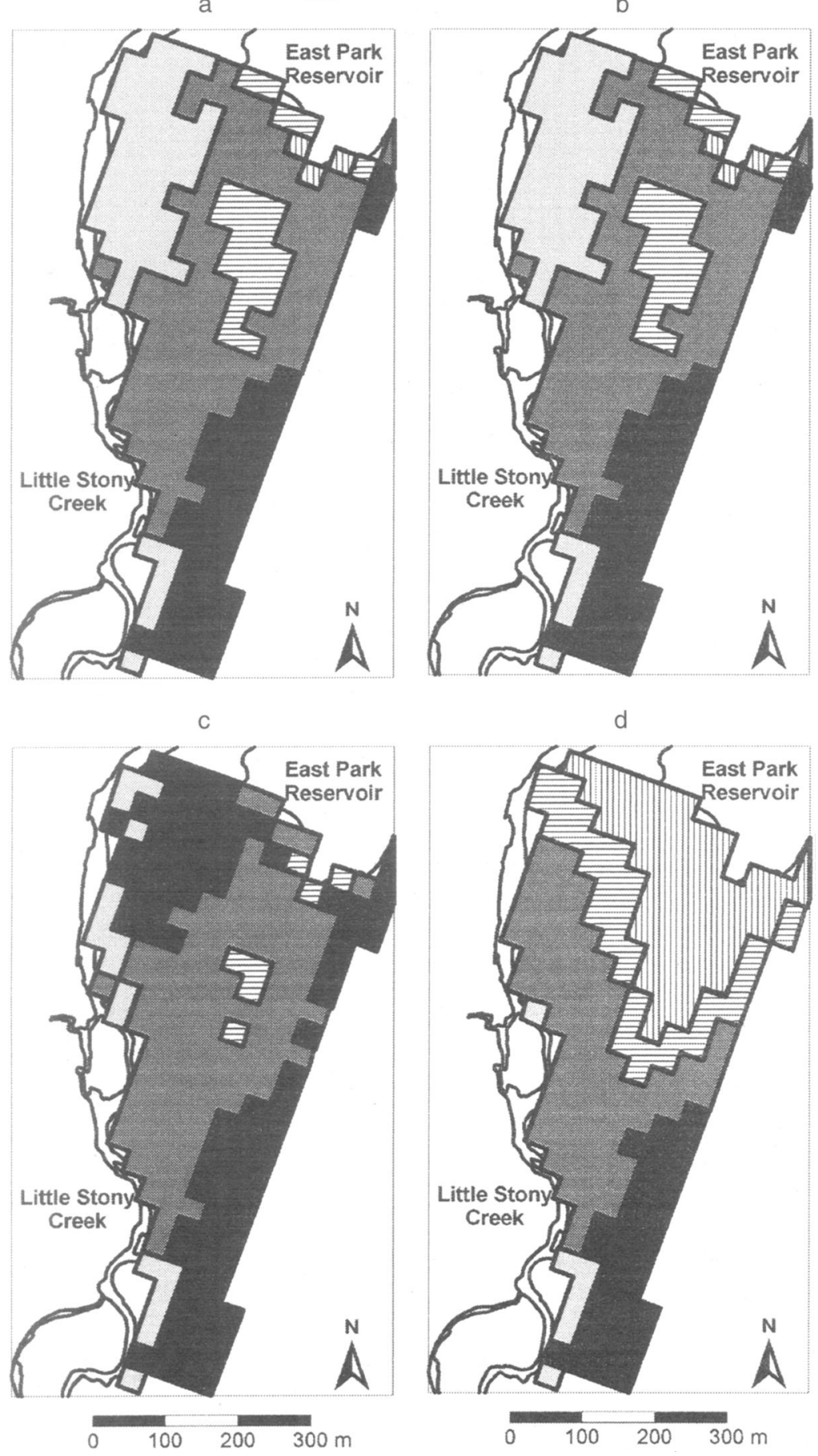

FIG. 9. Geographic extent of each community type from the Bayesian model selection procedure (a) for the existing condition, and for the existing condition with (b) late-drawdown, (c) full-drawdown, and (d) full-pool scenarios. 
TABLE 3. Geographic extent of each community type under each scenario from the Bayesian model averaging procedure.

\begin{tabular}{lcccc}
\hline \hline $\begin{array}{c}\text { Community } \\
\text { type }\end{array}$ & $\begin{array}{c}\text { Existing } \\
\text { area (ha) }\end{array}$ & $\begin{array}{c}\text { Existing with } \\
\text { late drawdown } \\
\text { area (ha) }\end{array}$ & $\begin{array}{c}\text { Full drawdown } \\
\text { area (ha) }\end{array}$ & $\begin{array}{c}\text { Full pool } \\
\text { area (ha) }\end{array}$ \\
\hline Grassland & $5.16 \pm 1.71$ & $5.16 \pm 1.71$ & $8.16 \pm 2.24$ & $3.65 \pm 0.76$ \\
Riverine forest & $3.35 \pm 2.04$ & $3.35 \pm 2.04$ & $1.40 \pm 0.81$ & $1.17 \pm 0.84$ \\
Sedge meadow & $6.26 \pm 3.49$ & $6.26 \pm 3.49$ & $6.22 \pm 3.27$ & $4.38 \pm 2.42$ \\
Willow forest & $3.74 \pm 2.66$ & $3.74 \pm 2.66$ & $3.22 \pm 2.39$ & $5.26 \pm 3.32$ \\
Emergent marsh & $1.70 \pm 1.33$ & $1.70 \pm 1.33$ & $1.22 \pm 1.09$ & $5.75 \pm 2.40$ \\
\hline
\end{tabular}

Note: Values are means $\pm 1 \mathrm{SD}$.

Thus, the distributions of grassland, sedge meadow, and emergent marsh might change rapidly in response to changes in reservoir operations, while the distributions of riverine forest and willow forest might remain unchanged for many decades in spite of changes in reservoir operations. Given sufficient prior knowledge, the prior probability term, discussed in greater detail below, could be used to model changes in vegetation distributions due to changes in reservoir operations over specified lengths of time. This was not pursued in this effort since the objective was not to understand specific species responses to specific changes in reservoir operations but, rather, to understand the behavior of riverine and reservoir-fringe systems and to generate hypotheses about the way that riverine and reservoir-fringe systems might develop under different reservoir operations.

Vegetation responses were modeled at the community-type level. However, vegetation tends to respond individualistically, and individualistic responses might be more appropriately modeled at the population level. The basic modeling approach described herein could be used to model vegetation responses at the population level. However, separate vegetation models would need to be constructed for each of the 62 species observed on the site, and the presentation and synthesis of the ensuing modeled results would be cumbersome and of uncertain management value. Furthermore, populations would almost certainly be clustered in the same general community types. For example, Bromus hordeaceous - the most prevalent species in the grasslandwould not be clustered with Typha domingensis-the most prevalent species in the emergent marsh-in any conceivable model scenario. Rather, Bromus hordeaceous would continue to be clustered with Centaurea solstitialis-the next most prevalent species in the grassland-in all model scenarios. Thus, modeling community-type responses is both convenient and justifiable in this case.

\section{Groundwater and flooding as primary and secondary gradients}

The vegetation model assumes that existing vegetation distributions are in equilibrium with a primary environmental gradient, that being depth to groundwater. This assumption is typically valid for wetlands where vegetation can be stressed by drought or soil saturation and associated root zone anoxia (Mitsch and Gosselink 1993). Shallow groundwater is critical in the recruitment and persistence of many riparian species (McBride and Strahan 1984, van Splunder et al. 1995, Stromberg et al. 1996, Mahoney and Rood 1998, Scott et al. 1998, Amlin and Rood 2002). Furthermore, oaks, maples, and eucalypts selectively use groundwater even when stream water is readily available, though the mechanisms and reasons for this phenomenon remain unclear (Dawson and Ehleringer 1991, Mensforth et al. 1994). The results presented herein indicate that vegetation distributions on the site are largely in equilibrium with depth to groundwater. The five community types occupy different locations on the mean depth to groundwater during the growing season gradient (Fig. 7). This is not merely coincidence, since the individual species that comprise these community types form functional groups, with obligate upland species on the dry end of the gradient and obligate wetland species on the wet end of the gradient (Table 1).

In some previous efforts, stream stage has been used in part as a surrogate for the water table (Auble et al. 1994, Primack 2000). This would be a poor assumption in this case since hydraulic heads under the delta are largely controlled by reservoir operations (Fig. 5). The groundwater backwater effect caused by the imposed reservoir stage creates a stable, shallow groundwater environment under the delta that is largely unaffected by changes in stream stage and/or regional groundwater pumping (Rains 2002). Thus, in this case, a groundwater model is required, particularly since the regionally unique community types are largely restricted to the delta.

If there were no riverine wetlands on the site-if, for example, there were only depressional, slope, lacustrine fringe, and/or poorly drained flat wetlandsthen vegetation distributions might be modeled effectively solely as functions of depth to groundwater. However, the recruitment of some riparian species is facilitated by flood disturbance since flood disturbance scours existing vegetation and deposits coarse-grained deposits, both of which provide favorable conditions for the recruitment of pioneer species (McBride and Strahan 1984, Stromberg et al. 1991, Auble and Scott 1998). Most of the observed species also are commonly 
observed in upland or non-riverine wetland systems (Hickman 1993, Sawyer and Keeler-Wolf 1995). Flooding, therefore, does not appear to be essential to the recruitment of most of the observed species. Regardless, riverine forest only occurs on recent flood deposits such as active floodplains, natural levees, and crevasse splays. Thus, riverine forest appears to require flooding, possibly due to the fact that frequent flooding creates a complex mosaic of surfaces that support high species richness and diversity (Fig. 6) and highly variable functional groups (Table 1).

Bayes' theorem is based upon axioms of probability theory that are well established and beyond debate (Hoeting et al. 1999, Wasserman 2000). Applications of Bayes' theorem, however, are somewhat controversial. The controversy centers on the prior probability term, since it is often unclear how prior knowledge can be converted into a secondary function that appropriately modifies a primary function. In this approach, a conservative approach is employed: flooding is used as a binary switch that is switched on for nodes that can flood and switched off for nodes that cannot flood. When the switch is on, riverine forest is allowed to occur; when the switch is off, riverine forest is not allowed to occur. Thus, flooding is simply a prerequisite that must be satisfied before riverine forest can occur. The remainder of the vegetation distributions are dependent solely upon the mean depth to groundwater during the growing season.

Certainly, other factors-such as competition, herbivory, and fire-can play important roles in vegetation distributions. By taking an empirical approach, the effects of other physical and biological factors are incorporated into this model effort. The basic assumption is that other physical and biological factors modify existing vegetation distributions along the primary and secondary gradients of mean depth to groundwater during the growing season and flooding. The primary and secondary gradients change as functions of changes in reservoir operations, but the modifying effects of other physical and biological factors remain constant. For example, the same competitive interactions occur, but the locations where these competitive interactions occur and the locations of the associated modified community type boundaries change as functions of changes in the underlying primary and secondary gradients.

\section{Definition of the growing season}

The growing season was defined as being from February to August, since field observations indicated that this interval encompassed the growing seasons for most of the species on the site. However, growing seasons vary by species, with some species having shorter growing seasons and some species having longer growing seasons. A sensitivity analysis was conducted to see if changes in the timing and duration of the growing season resulted in substantial changes in modeled vegetation distributions. The existing-condition scenario was simulated for all nine possible growing seasons that begin in January, February, or March and end in July, August, or September. Modeled vegetation distributions under all nine simulations were essentially identical.

\section{The importance of microtopographic relief}

In this application, elevations were assigned to 0.10ha blocks, which smoothed local but important microtopographic lows. An abandoned channel, for example, is located on the delta and is a location in which small areas of sedge meadow, willow forest, and emergent marsh occur. The abandoned channel is too small to be modeled given the lack of fine-resolution topographic data. Thus, this local but important microtopographic low is generally under-represented in the model.

Finer-resolution microtopographic data could be obtained by field or remote-sensing techniques. However, node spacing would need to be $\sim 3 \mathrm{~m}$, with each node representing 0.001 ha, to account for the abandoned channel on the delta. Thus, the model domain would need to contain more than 10000 nodes, each of which would need to be assigned a ground surface elevation. Obtaining this level of precision and accuracy by field surveying would be time consuming, while obtaining this level of precision and accuracy by remote-sensing techniques such as light detection and ranging (LIDAR) or interferometric synthetic aperture radar (IfSAR) would be less time consuming but much more expensive.

The expense and effort of obtaining finer-resolution microtopographic data are not justifiable in this case. The abandoned channel is $\sim 400 \mathrm{~m}$ in length and $3 \mathrm{~m}$ in width. The abandoned channel, therefore, covers $\sim 0.12$ ha of the 20.20 -ha model domain. Perhaps $75 \%$ ( $\sim 0.09 \mathrm{ha})$ supports sedge meadow in a grassland or sedge meadow matrix. The remaining $25 \%(\sim 0.03 \mathrm{ha})$ supports willow forest or emergent marsh in a sedge meadow, willow forest, or emergent marsh matrix. These areas are extremely small, particularly when considered with respect to the larger areas already modeled as sedge meadow, willow forest, and emergent marsh (Fig. 9, Table 3).

\section{Model simulations}

The groundwater backwater effect is a function of imposed reservoir stage and groundwater recharge from up-gradient sources. Reservoirs are constructed in valley-bottom positions where groundwater discharge occurs. When reservoirs are filled, imposed reservoir stages can be higher than local hydraulic heads and groundwater discharge to inundated areas can no longer occur. This has little to no effect on the rates of groundwater recharge from up-gradient sources. This incoming groundwater recharge accumulates in shallow groundwater storage prior to discharging at or near the reservoir fringe. This creates a stable, shallow groundwater environment on the reservoir fringe. This 
groundwater backwater effect can be inferred from previous studies of reservoirs (Cady 1941) and estuaries (Harvey and Odum 1990). Theoretical model results that predict this effect require that the depth of the local groundwater flow system be small relative to the width of the surface water body (McBride and Pfannkuch 1975). The site satisfies this requirement since the local groundwater flow system is $\sim 3$ m deep while East Park Reservoir directly down gradient is $\sim 500 \mathrm{~m}$ wide.

The groundwater backwater effect caused by the imposed reservoir stage is largely confined to the delta. This is consistent with previous hydrometric observations (Fig. 5; Rains 2002). Thus, changes in reservoir operations have few effects on modeled vegetation distributions on the terrace but can have pronounced effects on modeled vegetation distributions on the delta. Reservoir operations have been reasonably constant for many years, with rapid recharge early in the wet season and slow drawdown in the late wet and early dry seasons. Reservoir operations cease to affect shallow groundwater and associated vegetation in the model domain when the reservoir is drawn down to $\sim 364.50$ $\mathrm{m}$. At $364.50 \mathrm{~m}$, reservoir storage is $\sim 54150000 \mathrm{~m}^{3}$, $86 \%$ of the approximate full-pool storage of 62771000 $\mathrm{m}^{3}$. In an average year, mean reservoir stage exceeds $364.50 \mathrm{~m}$ only during the months of March through June. This is why modeled vegetation distributions for the existing condition and existing condition with latedrawdown scenarios are identical.

Modeled vegetation distributions under the fulldrawdown scenario are largely functions of the existing topographic relief. Grassland is the default community type throughout most of the valley, occurring extensively up and down valley of the reservoir. One might expect, therefore, for most of the model domain to revert to grassland under the full-drawdown scenario. However, sedge meadow, willow forest, and emergent marsh persist in the full-drawdown scenario on scoured surfaces on the upper and middle delta. These scoured surfaces are the abandoned floodway and abandoned channel that can be seen in various stages of development in serial aerial photographs dating back to 1948. The reservoir had to exist for these scoured surfaces to develop, but the reservoir need not continue to exist for these scoured surfaces to continue to support sedge meadow, willow forest, and emergent marsh. Meanwhile, grassland replaces some sedge meadow and riverine forest on depositional surfaces on the lower delta and the near-channel area. These depositional surfaces are largely the natural levees and crevasse splays that also can be seen in various stages of development in serial aerial photographs dating back to 1948 .

Modeled vegetation distributions under the full-pool scenario are largely functions of the groundwater backwater effect and the existing topographic relief. The scoured surfaces on the upper and middle delta are located in the off-channel area so the shallowest groundwater and the wettest community types extend in a lobe up the valley in the off-channel area. Sedge meadow, willow forest, and emergent marsh replace riverine forest on the natural levees and crevasse splays. The lower end of the model domain becomes emergent marsh with a fringe of willow forest. The expansion of the emergent marsh could enhance existing populations of the Tricolored Blackbird, since Tricolored Blackbirds preferentially nest in emergent marshes dominated by cattails (Typha spp.) and tules (Scirpus spp.) (Neff 1937, DeHaven et al. 1975). However, the loss of the riverine forest on the delta could diminish other wildlife populations.

\section{Management implications}

Changes in reservoir operations can have pronounced effects on shallow groundwater and associated vegetation distributions in riverine and reservoir-fringe systems. However, vegetation distributions in deltaic environments are somewhat resilient to change. Deltas have erosional environments, such as floodways and channels, and depositional environments, such as natural levees and crevasse splays. These erosional and depositional environments may provide refugia for vegetation to occupy under different reservoir operations. For example, erosional environments may support wetland species even under full-drawdown conditions, while depositional environments may support upland species even under full-pool conditions. Thus, each community type may persist, though the precise areas and locations of each community type may change. Nevertheless, the effects of changing reservoir operations must be considered or other elements of an overall management strategy (for example, reducing livestock grazing and/or planting additional vegetation to promote the expansion of existing plant and wildlife habitats) could fail to meet their desired objectives.

\section{ACKNOWLEDGMENTS}

The authors would like to thank the following agencies, organizations, and individuals for their contributions to this study. This study was funded by a cooperative agreement between the United States Bureau of Reclamation and Ducks Unlimited (Ducks Unlimited Agreement No. 1425-97-FC-2014630). Additional funding was provided by a gift from the Peter and Nora Stent Fund of the Peninsula Community Foundation. Neil Willits assisted with the Bayesian model selection and Bayesian model averaging procedures. Janice Fong drafted Figs. 1-3. Graham Fogg, Kai Rains, David Merritt, and one anonymous reviewer provided suggestions that greatly improved the quality of the manuscript.

\section{Literature Cited}

Amlin, N. M., and S. B. Rood. 2002. Comparative tolerances of riparian willows and cottonwoods to water-table decline. Wetlands 22:338-346.

Anderson, M. P., and W. W. Woessner. 1992. Applied groundwater modeling: simulation of flow and advective transport. Academic Press, New York, New York, USA.

Auble, G. T., J. M. Friedman, and M. L. Scott. 1994. Relating riparian vegetation to present and future streamflows. Ecological Applications 4:544-554. 
Auble, G. T., and M. L. Scott. 1998. Fluvial disturbanct $\rightarrow$ patches and cottonwood recruitment along the upper Missouri River, Montana. Wetlands 18:546-556.

Bertoldi, G. L., and W. C. Swain. 1996. California wetland resources. Pages 127-134 in J. D. Fretwell, J. S. Williams, and P. J. Redman, editors. National water summary of wetland resources. U.S. Geological Survey Water-Supply Paper 2425. U.S. Government Printing Office, Washington, D.C., USA.

Brown, R. D., Jr., 1964. Geologic map of the Stonyford Quadrangle, Glenn, Colusa, and Lake Counties, California. Mineral Investigations Field Studies Map MF-279. Scale 1:48,000. U.S. Geological Survey, Washington, D.C., USA.

Cady, R. C. 1941. Effect upon ground-water levels of proposed surface-water storage in Flathead Lake, Montana. U.S. Geological Survey Water-Supply Paper 849-B. U.S. Government Printing Office, Washington, D.C., USA.

Cairns, J., Jr., and S. E. Palmer. 1993. Senescent reservoirs and ecological restoration: an overdue reality check. Restoration Ecology 1:212-219.

Childers, D., D. L. Kresch, S. A. Gustafson, T. J. Randle, J. T. Melena, and B. Cluer. 2000. Hydrologic data collected during the 1994 Lake Mills drawdown experiment, Elwha River, Washington. U.S. Geological Survey Water-Resources Investigations Report 99-4215. U.S. Government Printing Office, Washington, D.C., USA.

Dahl, T. E., and G. J. Allord. 1996. History of wetlands in the conterminous United States. Pages 19-26 in J. D. Fretwell, J. S. Williams, and P. J. Redman, editors. National water summary of wetland resources. U.S. Geological Survey Water-Supply Paper 2425. U.S. Government Printing Office, Washington, D.C., USA.

Dahm, C. N., N. B. Grimm, P. Marmonier, H. M. Valett, and P. Vervier. 1998. Nutrient dynamics at the interface between surface waters and groundwaters. Freshwater Biology 40:427-451.

Dawson, T. E., and J. R. Ehleringer. 1991. Streamside trees that do not use stream water. Nature 350:335-337.

DeHaven, R. W., F. T. Crase, and P. D. Woronecki. 1975. Breeding status of the tricolored blackbird, 1969-1972. California Fish and Game 61:166-180.

Fetter, C. W. 1994. Applied hydrogeology. Third edition. Prentice Hall, Upper Saddle River, New Jersey, USA.

$\rightarrow$ Franz, E. H., and F. A. Bazzaz. 1977. Simulation of vegetation response to modified hydrologic regimes: a probabilistic model based on niche differentiation in a floodplair forest. Ecology 58:176-183.

Gosselink, J. G., and R. E. Turner. 1978. The role of hydrology in freshwater wetland ecosystems. Pages 63-78 in R. E. Good, D. F. Whigham, and R. L. Simpson, editors. Freshwater wetlands: ecological processes and management potential. Academic Press, New York, New York, USA.

Greco, S. E. 1999. Monitoring riparian landscape change and modeling habitat dynamics of the yellow-billed cuckoo on the Sacramento River, California. Dissertation. University of California, Davis, California, USA.

$\rightarrow$ Hamilton, W. J., III. 1998. Tricolored blackbird itinerant breeding in California. Condor 100:218-226.

Harbaugh, A. W., E. R. Banta, M. C. Hill, and M. G. McDonald. 2000. MODFLOW-2000, the U.S. Geological Survey modular ground-water model. User guide to modularization concepts and the ground-water flow process. U.S. Geological Survey Open-File Report 00-92. U.S. Government Printing Office, Washington, D.C., USA.

Hargreaves, G. H., and Z. A. Samani. 1982. Estimating potential evapotranspiration. Journal of the Irrigation and Drainage Division 108:225-230.

Hargreaves, G. H., and Z. A. Samani. 1985. Reference crop evapotranspiration from temperature. Applied Engineerin in Agriculture 1:96-99.
Harvey, J. W., and W. E. Odum. 1990. The influence of tidal marshes on upland groundwater discharge to estuaries. Biogeochemistry 10:217-236.

Hazen, A. 1911. Discussion: dams on sand formations. Transactions American Society of Civil Engineers 73:199.

Hickman, J. C. 1993. The Jepson manual. University of California Press, Berkeley, California, USA.

Hill, M. O. 1979. TWINSPAN-a FORTRAN program for arranging multivariate data in an ordered two-way table by classification of individuals and attributes. Cornell University, Ithaca, New York, USA.

Hoeting, J. A., D. Madigan, A. E. Raftery, and C. T. Volinsky. 1999. Bayesian model averaging: a tutorial. Statistical Science 14:382-401.

Jennings, C. W., and R. G. Strand. 1960. Geologic map of California, Ukiah sheet. Scale 1:250,000. State of California Division of Mines and Geology, Sacramento, Califor nia, USA.

Jensen, M. E., R. D. Burman, and R. G. Allen. 1990. Evapotranspiration and irrigation water requirements. ASCE manuals and reports on engineering practice no. 70. American Society of Civil Engineers, New York, New York, USA.

Jongman, R. H., C. J. F. ter Braak, and O. F. R. van Tongeren. 1987. Data analysis in community and landscape ecology. Pudoc, Wageningen, The Netherlands.

Kentula, M. E. 1996. Wetland restoration and creation. Pages 87-92 in J. D. Fretwell, J. S. Williams, and P. J. Redman, editors. National water summary of wetland resources. U.S. Geological Survey Water-Supply Paper 2425. U.S. Government Printing Office, Washington, D.C., USA.

Leake, S. A., and M. R. Lilly. 1997. Documentation of a computer program (FHB1) for assignment of transient specified-flow and specified-head boundaries in applications of the modular finite-difference ground-water flow model (MODFLOW). U.S. Geological Survey Open-File Report 97-571. U.S. Government Printing Office, Washington, D.C., USA.

Lilles, T. M., and R. W. Kiefer. 1994. Remote sensing and image interpretation. Third edition. John Wiley and Sons, New York, New York, USA.

Mahoney, J. M., and S. B. Rood. 1998. Streamflow requirements for cottonwood seedling recruitment-an integrative model. Wetlands 18:634-645.

McBride, J. R., and J. Strahan. 1984. Establishment and survival of woody riparian species on gravel bars of an intermittent stream. American Midland Naturalist 112:235245

McBride, M. S., and H. O. Pfannkuch. 1975. The distribution of seepage within lakebeds. Journal of Research of the U.S. Geological Survey 3:505-512.

Mensforth, L. J., P. J. Thorburn, S. D. Tyerman, and G. R. Walker. 1994. Sources of water used by riparian Eucalyptus camaldulensis overlying highly saline groundwater. Oecologia 100:21-28.

Mitsch, W. J., and J. G. Gosselink. 1993. Wetlands, second edition. Van Nostrand Reinhold, New York, New York, USA.

Moser, M., C. Prentice, and S. Frazier. 1997. A global overview of wetland loss and degradation. Pages 21-31 in The Ramsar Convention bureau staff, editors. Proceedings of the sixth meeting of the conference of the contracting parties, Brisbane, Australia, March 1996, Volume 10B/12. The Ramsar Convention Bureau, Gland, Switzerland.

Mueller-Dombois, D., and H. Ellenberg. 1974. Aims and methods of vegetation ecology. John Wiley and Sons, New York, New York, USA.

Neff, J. A. 1937. Nesting distribution of the tricolored redwing. Condor 39:61-81. 
Pasternack, G. B., W. B. Hilgartner, and G. S. Brush. 2000. Biogeomorphology of an upper Chesapeake Bay rivermouth tidal freshwater marsh. Wetlands 20:520-537.

Primack, A. G. B. 2000. Simulation of climate-change effects on riparian vegetation in the Pere Marquette River, Michigan. Wetlands 20:538-547.

Pusch, M., D. Fiebig, I. Brettar, H. Eisenmann, B. K. Ellis. L. A. Kaplan, M. A. Lock, M. W. Naegeli, and W. Traun spurger. 1998. The role of micro-organisms in the ecological connectivity of running waters. Freshwater Biology 40: 453-495.

Rains, M. C. 2002. Surface and ground-water origins and interactions and vegetation distributions in riverine and reservoir-fringe systems: a case study in support of reservoir management efforts. Dissertation. University of California, Davis, California, USA.

Rains, M. C., and J. F. Mount. 2002. Origin of shallow ground water in an alluvial aquifer as determined by isotopic and chemical procedures. Ground Water 40:552-563.

Reed, P. B., Jr. 1988. National list of plant species that occur in wetlands: California (Region 0). Biological Report 88(26.10). U.S. Department of the Interior, Fish and Wildlife Service, Washington, D.C., USA.

Sawyer, J. O., and T. Keeler-Wolf. 1995. A manual of California vegetation. California Native Plant Society, Sacramento, California, USA.

Scott, M. L., P. B. Shafroth, and G. T. Auble. 1998. Responses of riparian cottonwoods to alluvial water table declines. Environmental Management 23:347-358.

Searcy, J. K. 1960. Graphical correlation of gaging-station records. U.S. Geological Survey Water-Supply Paper 1541C. U.S. Government Printing Office, Washington, D.C., USA.

Searcy, J. K., and C. H. Hardison. 1960. Double-mass curves. U.S. Geological Survey Water Supply Paper 1541-B. U.S. Government Printing Office, Washington, D.C., USA.

Shuman, J. R. 1995. Environmental considerations for assessing dam removal alternatives for river restoration. Regulated Rivers: Research and Management 11:249-261.
Springer, A. E., J. M. Wright, P. B. Shafroth, J. C. Stromberg, and D. T. Patten. 1999. Coupling groundwater and riparian vegetation models to assess effects of reservoir releases. Water Resources Research 35:3621-3630.

Stromberg, J. C., D. T. Patten, and B. D. Richter. 1991. Flood flows and dynamics of Sonoran riparian forests. Rivers 2: 221-235.

Stromberg, J. C., R. Tiller, and B. D. Richter. 1996. Effects of groundwater decline on riparian vegetation of semi-arid regions - the San Pedro, Arizona. Ecological Applications 6:113-131.

ter Braak, C. J. F., and I. C. Prentice. 1988. A theory of gradient analysis. Advances in Ecological Research 18: 271-313.

U.S. Environmental Protection Agency and U.S. Department of Agriculture. 1998. Clean water action plan: restoring and protecting America's waters. National Center for Environmental Publications and Information, Cincinnati, Ohio, USA.

van Splunder, I., H. Coops, L. A. C. J. Voesenek, and C. W. P. M. Blom. 1995. Establishment of alluvial forest species in floodplains: the role of dispersal timing, germination characteristics and water level fluctuations. Acta Botanica Neerlandica 44:269-278.

Vervier, P., M. Dobson, and G. Pinay. 1993. Role of interaction zones between surface and ground waters in DOC transport and processing: considerations for river restoration. Freshwater Biology 29:275-284.

Ward, J. V., G. Bretschko, M. Brunke, D. Danielopol, D. Gibert, T. Gonser, and A. G. Hildrew. 1998. The boundaries of river systems: the metazoan perspective. Freshwater Biology 40:531-569.

Wasserman, L. 2000. Bayesian model selection and model averaging. Journal of Mathematical Psychology 44:92107.

Whittaker, R. H. 1967. Gradient analysis of vegetation. Biological Reviews of the Cambridge Philosophical Society 49:207-264

Zedler, J. B. 1977. Salt marsh community structure in the Tijuana Estuary, California. Estuarine and Coastal Marine Science 5:39-53. 